\title{
Pemberian Wasiat Wajibah Atas Harta Warisan Kepada Ahli Waris Non-Muslim Menurut Kompilasi Hukum Islam
}

\author{
Syans Dias Aulia Abiandti ${ }^{1}$, I Ketut Rai Setiabudhi ${ }^{2}$
}

${ }^{1}$ Fakultas Hukum Universitas Udayana, E-mail: syansturnitinjurnal@gmail.com

${ }^{2}$ Fakultas Hukum Universitas Udayana, E-mail: raisetiabudhi_fhunud@yahoo.com

\begin{tabular}{l}
\hline Info Artikel \\
\hline Masuk: 21 April 2021 \\
Diterima : 23 Juni 2021 \\
Terbit : 1 Juli 2021 \\
Keywords : \\
Heir;non-Muslimheirs; \\
mandatory will \\
\\
\\
\\
Kata kunci: \\
Pewaris; ahliwaris non \\
muslim; wasiatwajibah
\end{tabular}

\begin{abstract}
The purpose of writing is to know and analyze the regulation of wills in the provisions of figh and positive legal provisions in Indonesia, and the basis for consideration of the Judge is to grant inheritance rights in the form of compulsory wills to non-Muslim heirs. Normative legal research methods. The results of this study indicate that the provision of wills is only intended for adoptive parents or adopted children and not to be given to a non-Muslim as this is regulated in Article 209 KHI. Second, the basis for judges to grant compulsory wills for heirs of different religions is the jurispudence of the Supreme Court of the Republic of Indonesia Number 368/K/Ag/1995 on the basis of being the freedom that is owned by the Judge, and the Judge has the obligation to make legal discoveries using the historical interpretation method, sociological interpretation, and the analogue argumentum based on morals, justice and the masses of society.
\end{abstract}

\footnotetext{
Abstrak

Adapun tujuan penulisan adalahmengetahui dan menganalisis mengenai pengaturan wasiat wajibah dalam ketentuan fikih dan ketentuan hukum positif di Indonesia, dan dasar pertimbangan Hakim memberikan hak waris dalam bentuk wasiat wajibah kepada ahli waris non muslim. Metode penelitian hukum normatif. Hasil penelitian ini menunjukkan bahwa, pemberian wasiat wajibah hanya diperuntukkan kepada orang tua angkat atau anak angkat dan tidak untuk diberikan kepada seseorang non-muslim sebagiamana hal ini diatur pada Pasal 209 KHI. Kedua, dasar hakim pemberian wasiat wajibah bagi ahli waris beda agama adalah yurispudensi Mahkamah Agung Republik Indonesia Nomor 368/K/Ag/1995, atas dasar asas kebebasan yang dimilikioleh Hakim, dan Hakim memiliki kewajiban untuk melakukan penemuan hukum menggunakan metode penafsiran historis, penafsiran sosiologis, dan argumentum peranalogium dengan berlandasakan moral, keadilan dan kemashlatan masyarakat.
} 
10.24843/AC.2021.v06.i0

2.p14

\section{Pendahuluan}

Hukum waris di Indonesia berlaku dengan tiga sistem kewarisan, yaitu Hukum Waris Adat, Hukum waris Islam dan Hukum waris Perdata Barat. Keberlakuan hukum tersebut tidak dapat dipilih, namun berdasarkan hukum apa ia tunduk. Masyarakat adat Bali, maka akan tunduk terhadap hukum waris adat, umat Islam akan tunduk tehadap hukum waris Islam, dan bagi orang-orang yang tunduk pada hukum perdata barat, maka kewarisannya akan mengikuti hukum waris perdata barat. Waris dalam hukum Islam telah diatur secara jelas dan detail dalam Al Qur'an yaitu pada QS AnNisa ayat (7-8,11-12,176), QS An-Anfal ayat (75), serta QS Al-Ahzab ayat (6) yang bersifat tetap (qath'i). Al Qur' an telah menerangkan secara terperinci mengenai bagian anak laki-laki dan perempuan terhadap harta warisan. ${ }^{1}$

Islam memberikan bagian waris kepada setiap anak kandung dan tidak membedakan antara pria dengan wanita, setiap ahli waris baik pria maupun wanita mempunyai hak yang sama, yang membedakannya hanya besarnya saja, dikarenakan hukum waris Islam menekankan pada keadilan yang berimbang, dan bukan keadilan yang sama rata sebagai sesama ahli waris. ${ }^{2}$

Hukum waris dalam Islam mendapatkan perhatian yang besar karena dalam hukum waris mengatur mengenai peralihan kekayaan seseorang yang meninggal kepada keluarganya yang masih hidup. ${ }^{3}$ Pada dasarnya setiap orang yang mempunyai hubungan nasab dan hubungan pernikahan dengan pewaris berhak mendapatkan warisan. Namun ada beberapa hal yang dapat menghalangi seseorang dalam menerima harta warisan salah satunya karena adanya perbedaan agama antara pewaris dengan yang menerima warisan (ahli waris). Para ulama bersepakat bahwa adanya perbedaan agama antara pewaris dan ahli waris menjadi penghalang untuk saling mewarisi. ${ }^{4}$

Hal tersebut didasarkan pada hadist Rasulullah SAW yang diriwayatkan oleh Bukhari Muslim yang artinya: "Dari Usamah bin Zaid r.a, bahwa Nabi Muhammad SAW bersabda: orang Muslim tidak boleh mewarisi harta orang kafir, dan orang kafir tidak boleh mewarisi harta orang Muslim." Selain hadist tersebut, terrdapat juga hadist yang diriwayatkan oleh Ahmad, Abu Daud dan Ibnu Majah yang artinya: "Dari Abdullah bin Amr r.a, ia berkata, Rasulullah SAW bersabda: Tidak boleh, dua orang yang berlainan agama saling mewarisi". Berdasarkan dari kedua hadist tersebut, jelas menegaskan bahwa ahli waris yang memiliki agama yang berbeda dengan pewaris, maka tidak berhak atas harta warisan dan tidak dapat menjadi ahli waris dari

${ }^{1}$ Achyar,G. 2011). Panduan fikih Al-Mawarist. Fakultas Syariah IAIN Ar-Raniry. Banda Aceh.h.18

2 Bachtiar, M. (2012). Hukum Waris Islam Dipandang Dari Perspektif Hukum Berkeadilan

Gender. Jurnal Ilmu Hukum, 3(1), 1-43.h.7 DOI: http:/ / dx.doi.org/10.30652/jih.v3i01.1026

${ }^{3}$ Rofiq, Ahmad. (1998). Hukum Islam di Indonesia.Raja Grafindo Persada. Jakarta.h.356.

${ }^{4}$ Habiburrahman. (2011).Rekonstruksi hukum kewarisan Islam di Indonesia. Kencana. Jakarta.h.19 
pewaris. ${ }^{5}$ Selain dari ketentuan hadist tersebut, Kompilasi Hukum Islam (selanjutnya disingkat KHI) yang merupakan rangkuman dari berbagai kitab yang ditulis oleh ulama fikih dan menjadi referensi pada Pengadilan Agama serta menjadi sumber hukum bagi orang-orang yang beragama Islam menentukan pada Pasal 171 huruf c mengenai kewarisan, yaitu "Ahli waris adalah orang yang pada saat meninggal dunia mempunyai hubungan darah atau hubungan perkawinan dengan pewaris, beragama Islam dan tidak terhalang karena hukum untuk menjadi ahli waris." Namun pada Pasal 173 KHI menentukan, bahwa:

"seorang terhalang menjadi ahli waris apabila dengan putusan hakim yang telah mempunyai kekuatan hukum yang tetap, dihukum karena (a) dipersalahkan telah membunuh atau mencoba membunuh atau menganiaya berat para pewaris; (b) dipersalahkan secara memfitnah telah mengajukan pengaduan bahwa pewaris telah melakukan suatu kejahatan yang diancam dengan hukuman 5 tahun penjara atau hukuman yang lebih berat."

Berdasarkan ketentuan Pasal 173 KHI tersebut, tidak menentukan bahwa berbeda agama dapat menjadikan seseroang menjadi terhalang untuk mewaris. Adanya ketentuan yang berbeda antara Pasal 171 huruf c dan Pasal 173 KHI tersebut menyebabkan permasalahan mengenai kewarisan yang berbeda agama, dikarenakan KHI tidak mengatur bagian anak kandung non-muslim atas harta warisan dari pewaris, yang secara hukum Islam tidak berhak mendapat warisan dari pewaris yang beragama Islam.

Tidak adanya aturan tersebut, maka Hakim telah membuat suatu terobosan hukum baru dimana adanya pemberian harta warisan kepada anak kandung yang beragama non-muslim atau beberbeda keyakinan dengan pewaris melalui wasiat wajibah. Adapun beberapa putusan tersebut antara lain: Putusan MA No. 368K/AG/1995, Putusan Mahkamah Agung No.51K/AG/1999, Putusan MA No. 16K/AG/2010, Penetapan Pengadilan Agama Surabaya No.140/Pdt.P/2012/PA.SBY, dan Putusan Pengadilan Agama Kabanjahe No.2/Pdt.G/2011/PA.KBJ, Putusan Pengadilan Agama Medan No.1453I Pdt.G/2013/PA.Mdn dan Putusan Pengadilan Jember No.204/Pdt.G/2007/PA.Jr.

Pemberian wasiat dalam Kitab undang-Undang Hikum Perdata (KUHPer) dan KHI merangkainya dalam hukum kewarisan, namun terdapat perbedaan antara pemberian wasiat dengan pembagian warisan, walaupun keduanya saling terkait dan diatur dalam hukum yang sama, yakni hukum waris karena pemberian wasiat dan pembagian warisan ini adalah kegiatan yang akan berlanjut. ${ }^{6}$

Wasiat telah menjadi amalan atau praktek di lingkungan masyarakat Islam Indonesia. Baik yang terjadi dalam lingkungan keluarga maupun antara pihak yang tidak terikat tali persaudaraan. Baik dilakukan secara lisan maupun tertulis, hanya saja pelaksanaan wasiat tersebut tampaknya kabur. A pakah wasiat berdasarkan hukum Islam atau yang

5 Rizkal, R. (2016). Pemberian Hak Waris Dalam Hukum Islam Kepada Non-Muslim Berdasarkan Wasiat Wajibah. Jurnal Yudisial,9(2), 173-193. h.175. DOI: http:// dx.doi.org/10.29123/iv.v9i2.23

${ }^{6}$ Arif, M.R. (2017). Pemberian Wasiat Wajibah terhadap Ahli Waris Beda Agama. DE LEGA LATA: Jurnal Ilmu Hukum, 2(2),351-372.h.352. DOI: http:/ /10.31219/osf.io/9f5cj 
berdasarkan hukum-hukum yang lain. Mengingat wasiat merupakan suatu tindakan hukum dan membawa akibat- akibat hukum tertentu bagi pihak-pihak yang lain. Wasiat tidak jarang menimbulkan sengketa diantara pihak-pihak yang terkait.

Pemberian wasiat untuk orang yang tidak berhak atas warisan dikenal dengan wasiat wajibah, yang ditujukan kepada anak angkat/orang tua anak yang tidak berhak atas warisan. Sebagimana ketentuan mengenai wasiat wajibah diatur dalam Pasal 209 KHI, yaitu

(1) "Harta peninggalan anak angkat dibagi berdasarkan Pasal 176 sampai dengan Pasal 193 tersebut di atas, sedangkan terhadap orang tua angkat yang tidak menerima wasiat diberi wasiat wajibah sebanyak-banyaknya $1 / 3$ dari harta wasiat anak angkatnya".

(2) "Terhadap anak angkat yang tidak menerima wasiat diberi wasiat wajibah sebanyak-banyaknya 1/3 dari harta warisan orang tua angkatnya".

Pasal 209 KHI merupakan dasar pemberian wasiat wajibah, namun MA RI menyimpangi pasal tersebut dengan memberikan bagian harta warisan seorang muslim kepada ahli waris non muslim. ${ }^{8}$ Menurut berbagai kalangan, Putusan MA yang memberikan harta peninggalan pihak muslim kepada pihak non muslim merupakan bentuk itjihad dalam penemuan hukum dengan menggunakan metode yuridis sosiologis, dan merujuk pada pandangan Hazairin yang mengambil pendapat Ibn Hazm dimana menegaskan bahwa, "Islam adalah agama yang rahmatan lil'alamin yang menjunjung tinggi asas keadilan berimbang, asas kepastian (kemutlakan), asas individual dan asas bilateral". ${ }^{9}$ Namun hal ini tentu saja menimbulkan pertentangan yaitu ketika asas-asas mengenai aturan hukum kewarisan yang telah jelas dan terperinci justru dilanggar dengan alasan kemashalatan dan keadilan bagi masyarakat.

Berangkat dari adanya norma kosong terkait ahli waris non muslim terhadap harta warisan pewaris yang muslim, maka perlu dilakukan penelitian lebih lanjut, dikarenakan tidak adanya aturan tersebut dapat menimbulkan ketidakpastian terhadap ahli waris non muslim terhadap harta kekayaan pewaris. Untuk itu penelitian ini mengangkat judul "Pemberian Wasiat Wajibah Atas Harta Warisan Kepada Ahli Waris Non-Muslim Menurut Kompilasi Hukum Islam". Berdasarkan latar belakang masalah yang telah diuraikan dia atas, maka rumusan masalah dalam penelitian adalah (1) Bagaimana pengaturan mengenai keberadaan wasiat wajibah dalam ketentuan fikih dan ketentuan hukum positif di Indonesia; (2) Bagaimana dasar pertimbangan Hakim memberikan hak waris dalam bentuk wasiat wajibah kepada ahli waris non muslim?

Adapun tujuan dari penelitian ini adalah untuk memahami dan menganalisis mengenai pengaturan wasiat wajibah dalam ketentuan fikih dan ketentuan hukum positif di Indonesia; dan dasar pertimbangan Hakim memberikan hak waris dalam bentuk wasiat wajibah kepada ahli waris non muslim. Penelusuran terhadap tulisan

\footnotetext{
${ }^{7}$ Ramdhani, Ria. (2015). Pengaturan Wasiat Wajibah Terhadap Anak Angkat Menurut Hukum Islam. Lex et Societatis, 3(1), 55-63, h.56.

8 Jahar, Asep Saepuddin. (2013). Hukum Keluarga, Pidana dan Bisnis. Kencana Prenada Media.Jakarta.h.94

${ }^{9}$ Ibid.h.98
} 
terdahulu yang digunakan sebagai panduan dan acuan, yaitu berupa artikel-artikel antara lain artikel berjudul "Pemberian Wasiat Wajibah Terhadap Ahli Waris Beda Agama (Kajian Perbandingan Hukum Antara Hukum Islam dan Putusan Mahkamah Agung Nomor 368.K/AG/1995)" oleh Muhammad Rinaldi Arif dari Badan Pengelola Pajak dan Retribusi Daerah Kota Medan pada tahun 2017 yang meneliti mengenai pertimbangan hukum mengenai pemberian wasiat wajibah terhadap ahli waris beda agama dan perbandingan putusan Mahkamah Agung Nomor 368.K/AG/1995 dan fikih Islam. ${ }^{10}$ Artikel berjudul "Wasiat Wajibah Sebagai Wujud Penyelesaian Perkara Waris Beda Agama Dalam Perkembangan Sosial Masyarakat" oleh Zulfia Hanum dan Alfi Syahr dari Puslitbag Mahkamah Agung Republik Indonesia, Jakarta pada tahun 2016 yang meneliti mengenai pemberian wasiat wajibah dan besaran porsinya serta yang menjadi pertimbangan dari pemberian wasiat wajibah. ${ }^{11}$

Berdasarkan artikel-artikel tersebut terdapat perbedaan dengan apa yang akan diteliti oleh penulis. Pada penelitian ini penulis meneliti mengenai pengaturan wasiat wajibah dalam ketentuan fikih dan ketentuan hukum positif di Indonesia dan dasar pertimbangan Hakim memberikan hak waris dalam bentuk wasiat wajibah kepada ahli waris non muslim, sedangkan pada artikel tersebut mengenai perbandingan putusan Mahkamah Agung Nomor 368.K/AG/1995 dan porsi dari pemberian wasiat wajibah.

\section{Metode Penelitian}

Penelitian ini adalah penelitian hukum normatif dengan menganalisis peraturan perundang-undangan yang berlaku terhadap suatu permasalahan hukum tertentu. Penelitian hukum normatif adalah penelitian yang meletakkan hukum sebagai sebuah bangunan sistem norma, yang terdiri dari asas-asas, norma, kaidah dari peraturan perundangan, putusan pengadilan, perjanjian serta doktrin (ajaran). ${ }^{12}$ Penelitian normatif hukum dipandang identik dengan norma-norma tertulis, yang dibuat dan diundangkan oleh lembaga atau pejabat yang berwenang dan meninjau hukum sebagai suatu sistem normatif yang otonom, mandiri, tertutup dan terlepas dari kehidupan masyarakat nyata. ${ }^{13}$ Pada penelitian ini pendekatan yang dipergunakan adalah pendekatan undang-undang, dengan menelaah semua peraturan perundangundangan dan regulasi yang berkaitan dengan dengan isu hukum yang ditangani, ${ }^{14}$ dimana adanya kekosongan hukum tentang pengaturan terkait hak anak kandung non

${ }^{10}$ Arif, M.R. (2017). Pemberian Wasiat Wajibah terhadap Ahli Waris Beda Agama. DE LEGA LATA: Jurnal Ilmu Hukum, 2(2),351-372. DOI: http:/ /10.31219/osf.io/9f5ci

11 Syahr, Z. H. A. (2016). Wasiat Wajibah sebagai Wujud Penyelesaian Perkara Waris Beda Agama dalam PerkembanganSosial Masyarakat. Holistik, 1(2), 123-133. DOI: $10.24235 /$ holistik.v1i2.905

${ }^{12}$ Sonata, Depri Liber. (2017).Metode Penelitian Hukum Normatif dan Empiris: Karakteristik Khas Dari Metode Meneliti Hukum. Fiat Justitia: Jurnal Ilmu Hukum. 8(1), 1-35. h.25. DOI: 10.25041 / fiatjustisia

${ }^{13}$ Soemitro, Ronny Hanitijo. (2008) Metode Penelitian Hukum dan Jurimetri. Alumni: Jakarta. h.1314.

${ }^{14}$ Mandasari, Zayanti. (2014).Politik Hukum Pengaturan Masyarakat Hukum Adat (Studi Putusan Mahkamah Konstitusi). Jurnal Hukum IUS QUIA IUSTUM.2(1), 227-250. h.231. DOI: https:// doi.org/10.20885/iustum.vol21.iss2.art4 
muslim terhadap harta warisan orang tuanya yang muslim, teknik yang dipergunakan untuk mengumpulkan bahan hukumnya adalah menggunakan tehnik bola salju, dan analisis bahan hukum menggunakan tehnik deskriftif dan kualitatif.

\section{Hasil Dan Pembahasan}

\subsection{Pengaturan Wasiat Wajibah Menurut Ketentuan Fiqih Dan Hukum Positif Di Indonesia}

Istilah wasiat wajbah tidak dikenal oleh para kalangan ulama, kalangan ulama hanya mengenal hukum melaksanakan wasiat, yaitu apakah pelaksanaan wasiat merupakan suatu keharusan dan cenderung diwajibkan atau hanya sebatas anjuran (sunah), yang mendaptkan pahala jika dilakukan dan bukan merupakan dosa jika tidak dilakukan/tidak dilaksanakan. ${ }^{15}$ Menurut Anshoruddin, "wasiat wajibah adalah tindakan yang dilakukan oleh penguasa atau hakim sebagai aparat negara yang memaksa atau memberi putusan wajib wasiat bagi orang yang telah meninggal dunia, yang diberikan kepada orang tertentu dalam keadaan tertentu pula. Dengan demikian, wasiat wajibah adalah wasiat yang dipandang telah dilakukan oleh seseorang yang meninggal dunia, walaupun sebenarnya ia tidak meninggalkan wasiat tersebut."16

Istilah wasiat wajibah pertama kali bermula dari Mesir, yaitu adanya cucu yang terhalang mendapatkan warisan, sehingga Ulama Mesir melakukan itjihad dan mengeluarkan fatwa sebagai solusinya, yaitu bahwa 'cucu' yang tidak mendapat warisan karena terhalang oleh anak laki-laki dapat diberikan harta warisan dalam bentuk wasiat wajibah, dengan ketentuan: ${ }^{17}$

1. Kalau dari garis keturunan laki-laki maka perlu berlaku seterusnya sampai ke bawah tetapi kalau dari garis keturunan anak perempuan hanya terbatas sampai pada anak atau anak-anak dari anak perempuan dari pewaris saja.

2. Pewaris di masa hidupnya belum pernah memberikan harta kepada yang berhak menerima wasiat wajibah tersebut seukuran hak wasiat wajibahnya.

3. Besarnya wasiat wajibah hanyalah sepertiga harta, entah yang berhak menerima wasiat wajibah itu banyak atau sedikit, campuran antara laki-laki atau perempuan maupun tidak. Kalau yang berhak menerima wasiat wajibah tersebut campuran antara laki-laki dan perempuan maka bagian mereka adalah dua banding satu $(2: 1)$.

4. Wasiat wajibah didahulukan dari wasiat biasa. Kalau pewaris telah membuat wasiat kepada mereka yang berhak menerima wasiat wajibah tetapi kurang jumlahnya dari sepertiga maka dicukupkanlah sampai jumlah sepertiga, tetapi bila telah melebihi dari sepertiga maka kelebihan itu dianggap wasiat biasa. Kalau yang berhak menerima wasiat wajibah tersebut lebih dari seorang, maka ada yang diberi wasiat biasa dan ada yang tidak maka yang belum diberi tersebut berhak mendapatkan hak bagian wasiat wajibahnya. Kalau pewaris ada membuat surat wasiat bisa dan ada pula meninggalkan

\footnotetext{
${ }^{15}$ Rizkal, R. Op.Cit. h.182

${ }^{16}$ Anshoruddin. Lembaga Wasiat Wajibah dalam Kompilasi Hukum Islam dalam Perspektif Sosiologi. DalamSyahr,Z.H. A. (2016). Wasiat Wajibah sebagai Wujud Penyelesaian Perkara Waris Beda Agama dalam Perkembangan Sosial Masyarakat. Holistik, 1(2), 123-133.h.125.
}

DOI: 10.24235/holistik.v1i2.905

17 Ibid. 
mereka yang berhak menerima wasiat wajibah maka wasiat wajibah dibayar dulu dalam batas sepertiga, kemudian baru diambilkan untuk wasiat biasa dalam batas sepertiga pula (sesudah diambil untuk wasiat wajibah).

Terkait wasiat, para jumhur ulama fiqih berbeda pendapat mengenai hukum berwasiat, sebagiamana hal ini dapat dikemukakan sebagai berikut: ${ }^{18}$

1. Menurut pandangan para Imam Mazhab bahwa kewajiban wasiat yang terdapat pada Surah Al-Baqarah ayat 180 itu telah dihapus dengan Surah An-Nisa ayat 11 tentang warisan. Maka dari itu, para Imam Mazhab berpendapat bahwa berwasiat kepada ibu bapak dan karib kerabat yang tidak menerima bagian waris itu hukumnya tidak wajib;

2. Daud Az zahiri yang didukung oleh Masruq, Tawus, Iyas, Qatadah, dan Ibnu Jarir berpendapat bahwa wasiat kepada ibu bapak dan karib kerabat yang menjadi ahli waris telah terhapuskan dengan kewajiban menerima warisan, tetapi wasiat kepada ibu bapak dan karib kerabat yang tidak menjadi ahli waris hukumnya wajib, mereka berpegang kepada Surah Al-Baqarah ayat 180; dan

3. Ibnu Hazm berpendapat bahwasanya memberi wasiat itu hukumnya wajib bagi setiap orang yang akan meninggal dan mempunyai harta peninggalan. Ia beralasan pada ketentuan Surah An-Nisa ayat 11 dan 12 yang mengajarkan bahwa adanya kewajiban untuk memisahkan harta peninggalan sesuai dengan bagian yang telah ditentukan dalam nash tersebut. Namun dalam ayat tersebut juga dinyatakan bahwa pelaksanaan wasiat dan pembayaran hutang. Logika formil menyatakan bahwa karena pembagian waris itu sendiri hukumnya wajib, maka pembayaran hutang dan melaksanakan wasiat yang harus didahulukan itu hukumnya juga wajib. Selanjutnya Ibnu Hazm juga beralasan bahwa membedakan status hukum membayar hutang dan melaksanakan wasiat dengan pembagian waris itu tidak tepat karena ketiga masalah tersebut itu tersurat dalam satu ayat yang terpisah-pisah.

Berdasarkan beberapa pendapat di atas terkait wasiat, maka dapat diketahui adanya perbedaan pendapat para jumhur ulama fiqih, yaitu sebagian kalangan berpendapat tidak adanya keharusan seseorang berwasiat karena telah digantikan dengan ketentuan mengenai waris, sedangkan sebagian lainnya berpendapat wasiat merupakan sesuatu yang wajib dilakukan sebelum seseorang meninggal dunia. Jika melihat sejarah mengenai hukum keluarga dalam Islam, maka Indonesia membaharui hukum keluarga paling belakang yaitu pada Tahun 1974 dengan diberlakukannya Undang-Undang Nomor 1 Tahun 1974 tentang Perkawinan. Terkait wasiat maka pengaturannya terdapat dalam Komplasi Hukum Islam (KHI) dengan bentuk Instruksi Presiden (Inpres) Nomor 1 Tahun 1991 yang berisi tentang ketentuan wasiat wajibah. ${ }^{19}$

Secara yuridis, pengaturan wasiat wajibah terdapat dalam Pasal 209 KHI." Adapun isi Pasal 209 KHI, yaitu:

(1) “Harta peninggalan anak angkat dibagi berdasarkan Pasal 176 sampai

18 Tono, S. (2012). Kedudukan wasiat dalam system pembagian harta peninggalan. Jakarta: Kementerian Agama Republik Indonesi Direktoral Jenderal Pendidikan Direktorat Pendidikan Tinggi. h.52.

19 Hidayati, S.(2012). Ketentuan wasiat wajibah dipelbagai Negara Muslim kontemporer. AHKAM: Jurnal Ilmu Syariah, 12(1).81-90. h.89 DOI: 10.15408/ajis.v12i1.982. 
dengan Pasal 193 tersebut di atas, sedangkan terhadap orang tua angkat yang tidak menerima wasiat diberi wasiat wajibah sebanyak-banyaknya $1 / 3$ dari harta wasiat anak angkatnya.

(2) Terhadap anak angkat yang tidak menerima wasiat diberi wasiat wajibah sebanyak-banyaknya 1/3 dari harta warisan orang tua angkatnya."

Berdasarkan ketentuan tersebut, bahwa pemberian wasiat wajibah hanya diperuntukkan kepada orang tua angkat atau anak angkat dan tidak dapat diberikan kepada non muslim, dikarenakan menyesuaikan aturan dalam syariat islam dan hukum islam itu sendiri. ${ }^{20}$ Sofyan Adhi Styawan juga memiliki pandangan yang sama, yaitu: ${ }^{21}$

“Bahwa apa yang sudah ada dan sudah diatur dalam KHI serta hadist di atas itu tidak dapat ditafsirkan dengan sendirinya karena seorang yang memiliki hubungan darah sekalipun atau memiliki hubungan perkawinan jika orang tersebut beragama non-muslim kedudukannya tidak dapat menjadi ahli waris dari Muslim. Jadi ketika hakim memberikan ijtihad menyamakan kedudukannya yang diganti dengan penetapan wasiat wajibah tentu tidak dapat dibenarkan, karena dalam Pasal 209 KHI tentang wasiat wajibah juga tidak mengatur bahwa anak angkat kedudukannya sama dengan anak yang memiliki hubungan darah langsung dengan pewaris."

Pemberian wasiat wajibah kepada non muslim berawal dari dikeluarkannya Putusan Mahkamah Agung Nomor $331 \mathrm{~K} / \mathrm{Ag} / 2018$, yang bersandar pada yurispudensi Mahkamah Agung Republik Indonesia Nomor 368/K/Ag/1995 tertanggal 16 juli 1998 dan Yurisprudensi Mahkamah Agung Republik Indonesia Nomor 51 K/Ag/1999 tanggal 29 September 1999 yang dalam salah satu pertimbangannya menyatakan bahwa anak kandung Non Muslim bukan ahli waris, namun tetap berhak untuk mendapatkan bagian harta warisan dengan mendasarkan pada wasiat wajibah karena memandang kapasitasnya sebagai penerima wasiat bukan sebagai ahli waris walaupun tidak diwasiatkan sebelumnya. Pemberian wasiat wajibah ini telah diterapkan dalam beberapa putusan pengadilan antara lain yaitu Putusan Nomor 0140 /Pdt. P/ 2012 /PA.Sby dan Putusan Nomor 218 K/Ag/2016 yang memberikan wasiat wajibah kepada seseorang yang beragama non muslim.

Pemberian wasiat wajibah oleh hakim kepada ahli waris non muslim merupakan bentuk kewajiban hakim sebagaimana diatur pada Pasal 5 ayat (1) Undang- Undang Nomor 48 Tahun 2009 Tentang Kekuasaaan Kehakiman yang menentukan, bahwa "Hakim dan hakim konstitusi wajib menggali, mengikuti, dan memahami nilai-nilai hukum dan rasa keadilan yang hidup dalam masyarakat." Hal in dikarenakan KHI tidak mengatur hal tersebut, sehingga hakim membuat terobosan baru dengan memberikan bagian harta warisan pewaris kepada ahli waris non muslim dalam bentuk wasiat wajibah dengan berlandasakan moral, keadilan dan kemashlatan.

${ }^{20}$ Rahario, A. P., \& Putri, E. F. D. (2019). Analisis Pemberian Wasiat Waiibah terhadap Ahli Waris Beda Agama Pasca PutusannMahkamah Agung Nomor $331 \mathrm{~K} / \mathrm{Ag} / 2018$. Jurnal Suara Hukum, 1(2), 172-185. DOI: http://dx.doi.org/10.26740/jsh.v1n2.p172-185

${ }^{21}$ Apriyudi, Eka.(2018).Pembagian Harta Warisan Anak Kandung Non Muslim Melalui Wasiat Wajibah. Jurnal Kertha Patrika, 40(1), 45-60. h.55-56. DOI:10.24843/KP.2018.v40.i01.p05 


\subsection{Dasar Pertimbangan Hakim Memberikan Hak Waris Dalam Bentuk Wasiat Wajibah Kepada Ahli Waris Non Muslim}

Setiap ahli waris di Indonesia baik yang muslim maupun non muslim harus tunduk pada sistem hukum yang berlaku padanya dan tidak dapat memilih system hukum mana yang akan digunakan terutama terkait pembagian harta warisan. Jika pewaris seorang muslim maka pembagian warisnya adalah menggunakan sistem hukum islam. Begitu juga terhadap pewaris muslim yang meninggalkan ahli warisnya non muslim, maka ketentuan pembagian warisnya juga menggunakan Hukum Waris Islam, karena kewarisan yang berlaku ialah berdasarka agama yang dipeluk oleh pewaris semasa hidupnya. ${ }^{22}$

Hukum kewarisan Islam menetukan adanya penghalang seseorang untuk mendapatkan bagian waris, sebagaimana hal tesebut diatur pada Pasal $173 \mathrm{KHI}$, yaitu:

"Seorang terhalang menjadi ahli waris apabila dengan putusan hakim yang telah mempunyai kekuatan hukum yang tetap, dihukum karena: (a) dipersalahkan telah membunuh atau mencoba membunuh atau menganiaya berat para pewaris;

(b) dipersalahkan secara memfitnah telah mengajukan pengaduan bahwa pewaris telah melakukan suatu kejahatan yang diancam dengan hukuman 5 tahun penjara atau hukuman yang lebih berat."

Selain hal-hal yang diatur dalam Pasal 173 KHI tersebut, ada hal lain yang tidak disebutkan secara khusus oleh KHI, yaitu agama yang diyakini ahli waris, sebagiamana hal tersebut tersirat dari pasal 171 huruf (c) KHI yang mendefinisikan ahli waris, yaitu:

"Ahli waris adalah orang yang pada saat meninggal dunia mempunyai hubungan darah atau hubungan perkawinan dengan pewaris, beragama Islam dan tidak terhalang karena hukum untuk menjadi ahli waris." Berdasarkan ketentuan tersebut, berlainan agama adalah halangan bagi seorang menjadi ahli waris, sehingga ia tidak berhak atas warisan layaknya ahli waris lainnya. Ketentuan ini merupakan kesepakatan sebagian ulama yang menentukan 3 hal yang menjadi halangan seseorang menjadi ahli waris yaitu karena perbudakan, pembunuhan, dan perbedaan agama.

Ketentuan ini ini kemudian dikuatkan oelh hadits Rasulullah SAW, "menurut Bukhori dan Muslim, dari Usamah bin Zaid, Rasulullah bersabda yang artinya adalah: Tidak mewaris seorang muslim terhadap non-muslim, demikian juga tidak mewaris seorang non-muslim terhadap orang muslim." Berdasarkan hadist tersebut, maka agama adalah salah satu syarat seseorang berhak atas bagian harta warisan. ${ }^{23}$

Faktor perbedaan agama yang menjadi penghalang bagi ahli waris untuk

22 Noviyanti, Liana.(2019). Penerapan Wasiat Wajiban Terhadap Non Muslim Ditinjau Dari Kompilasi Hukum Islam (KHI) Studi Kasus Putuan Mahkamah Agung No.331/K/AG/2018/MA.Jurnal Hukum Adigama, 2(2), 1-29. h.9-10. DOI: http:/ / dx.doi.org/10.24912/adigama.v2i2.6533

${ }^{23}$ Nugraheni, D.B., Ilhami, H., \& Harahab, Y. (2010). Pengaturan dan implementasi wasiat wajibah di Indonesia. Mimbar Hukum-Fakultas Hukum Universitas Gadjah Mada, 22(2),311329.h.318. DOI: https:/ / doi.org/10.22146/jmh.16229 
mendapatkan harta warisan pewaris, ternyata implemantasinya berbeda dalam praktek pengadilan. Salah satunya putusan Putusan Mahkamah Agung Nomor $331 \mathrm{~K} / \mathrm{Ag} / 2018$ yang memutuskan ahli waris non muslim berhak memperoleh harta warisan pewaris berdasarkan Wasiat Wajibah sebesar 1/4 bagian dari harta warisan pewaris. Menurut putusan ini, terlihat bahwa agama yang berbeda menghalangi seseorang untuk mendapatkan bagian waris diabaikan melalui penetapan Wasiat Wajibah.

Menurut Abdul Gani Abdullah selaku mantan Hakim Agung mengatakan bahwa "pertimbangan dalam memberikan putusan hakim tidak hanya berpegang pada KHI, hakim punya kewenangan mempertimbangkan dasar-dasar hukum yang lain selain KHI, dan dapat menggambil pendapat-pendapat dalam kitab Figh mengenai seorang ahli waris yang terhijab kewarisannya karena perbedaaan agama. Oleh sebab itu hakim tidak harus berpegang dengan KHI, tetapi bisa juga dari yurisprudensi, karena majelis hakim dapat meninjau kepada apa yang dapat memberikan keadilan bagi para pihak." ${ }^{24}$ Adapun yang menjadi dasar pertimbangan hakim, antara lain: ${ }^{25}$

1. Faktor historis, yaitu pendapat para ulama dari kalangan Syafi'iyah, Hanafiyah, dan Hanabilah yang membolehkan berwasiat untuk mereka nonmuslim dengan syarat bahwa yang bersangkutan tidak memerangi umat Islam. Secara historis, perbedaan agama sebagai halangan mendapatkan waris dianggap hanya merupakan masalah politis, dan dapat ditinggalkan bila kemudian kondisi telah berubah sebagaimana yang terjadi pada masa ini. Berdasarkan hal inilah, maka para hakim berpendapat bahwa larangan untuk memberikan bagian waris bagi ahli waris yang terhalang akibat perbedaan agama pada saat ini dapat disimpangi.

2. Penggunaan metode interpretasi sosiologis dalam melakukan penemuan hukum dimana hakim dilarang menolak perkara dengan alasan tidak ada hukumnya (ius curia novit) karena hakim memiliki kewenangan untuk melakukan penemuan hukum (rechtsvinding). Interpretasi sosiologis diawali dengan pemahaman bahwa ketentuan mengenai hukum kewarisan Islam merupakan lex specialis dari hukum Islam dan hukum Islam adalah lex generalis. Berdasarkan hal tersebut, ketika kemudian hakim tidak menemukan ketentuan mengenai Wasiat Wajibah bagi ahli waris non muslim dalam hukum kewarisan Islam sebagai lex specialis, maka hakim melakukan penemuan hukum dengan mengembalikan persoalan pada lex generalis yaitu ketentuan hukum Islam secara umum.

3. Penggunaan metode argumentum per analogium dalam melakukan penemuan hukum karena adanya kekosongan hukum, yaitu dengan cara menemukan ketentuan hukum lain yang sejenis, memiliki kemiripan, serta adanya tuntutan dalam masyarakat untuk mendapatkan penilaian yang sama, dalam hal ini menggunakan ketentuan Wasiat Wajibah yang ada di dalam KHI khusus untuk anak angkat dan atau orang tua angkat.

4. Eksistensi hukum kewarisan Islam di antara sistem hukum kewarisan lainnya, yaitu hukum waris BW dan hukum waris adat, dimana ketiganya digunakan sebagai pilihan hukum bagi rakyat Indonesia. Penemuan hukum yang memberikan Wasiat Wajibah bagi ahli waris non muslim merupakan upaya

${ }^{24}$ Noviyanti, Liana. Op.Cit.h.23.

${ }^{25}$ Nugraheni, D. B., Ilhami, H., \& Harahab, Y. Op.Cit. h.323-324. 
mengaktualisasikan hukum Islam di tengah-tengah masyarakat Indonesia yang pluralistik baik di bidang sosial, budaya, hukum, maupun agama.

5. Pilihan agama sebagai bagian dari hak asasi manusia

6. Teori hukum mengenal asas hukum dan penyimpangan terhadap asas hukum, dimana berdasarkan asas hukum kewarisan Islam adalah terhalangnya seorang ahli waris untuk mendapatkan bagian warisan karena memeluk agama yang berbeda dengan pewaris, maka terhadap asas hukum ini kemudian terbuka pintu penyimpangan yaitu melalui Wasiat Wajibah. Penetapan Wasiat Wajibah oleh hakim akan memberikan hak atas bagian warisan bagi mereka yang berdasarkan asas hukum tidak mendapatkan bagiannya. Wasiat Wajibah adalah penyimpangan terhadap asas hukum dalam hukum kewarisan Islam tersebut. Adapun dasar pertimbangan Hakim memberikan hak waris dalam bentuk wasiat wajibah kepada ahli waris non muslim adalah berdasarkan yurispudensi Mahkamah Agung Republik Indonesia Nomor 368/K/Ag/1995, yang memutuskan bahwa "anak kandung perempuan yang beragama non Islam (Nasrani) status hukumnya bukan ahli waris, namun ia berhak mendapat bagian dari harta peninggalan kedua orangtuanya almarhum berdasarkan wasiat wajibah yang bagiannya sama dengan bagian anak perempuan ahli waris almarhum ayahnya dan almarhumah ibunya yang beragama islam."

\section{Kesimpulan}

Hasil penelitian ini menyimpulkan bahwa: pertama, berdasarkan Pasal 209 KHI, wasiat wajibah diperuntukkan untuk orang tua angkat/anak angkat dan tidak dapat diberikan kepada non muslim dengan dasar perbedaan agama menjadi halangan menjadi ahli waris, namun adanya yurisprudensi MA Nomor 368/K/Ag/1995, yang memutuskan bahwa "anak kandung perempuan yang beragama non Islam (Nasrani) status hukumnya bukan ahli waris, namun ia berhak mendapat bagian dari harta peninggalan kedua orangtuanya almarhum berdasarkan wasiat wajibah yang bagiannya sama dengan bagian anak perempuan ahli waris almarhum ayahnya dan almarhumah ibunya yang beragama islam," sehingga membuat orang berbeda agama dapat menerima wasiat wajibah. Kedua, dasar hakim pemberian wasiat wajibah bagi ahli waris beda agama adalah, bahwa hakim dengan asas kebebasan yang dimilikinya, memiliki kewajiban untuk melakukan penemuan hukum menggunakan metode penafsiran historis, penafsiran sosiologis, dan argumentum peranalogium dengan berlandasakan moral, keadilan dan kemashlatan masyarakat.

\section{Daftar Pustaka / Daftar Referensi}

\section{$\underline{B u k u}$}

Achyar, G. (2011). Panduan fikih Al-Mawarist 1. Fakultas Syariah IAIN Ar-Raniry. Banda Aceh.

Ahmad Rofiq. (2003). Hukum Islam di Indonesia.Raja Grafindo Persada. Jakarta.

Habiburrahman. (2011). Rekonstruksi hukum kewarisan Islam di Indonesia. Kencana. 
Jakarta.

Jahar, Asep Saepuddin. (2013). Hukum Keluarga, Pidana dan Bisnis. Kencana Prenada Media. Jakarta.

Soemitro, Ronny Hanitijo. (2008) Metode Penelitian Hukum dan Jurimetri. Alumni. Jakarta.

Tono, S. (2012). Kedudukan wasiat dalam sistem pembagian harta peninggalan. Jakarta: Kementerian Agama Republik Indonesia Direktoral Jenderal Pendidikan Direktorat Pendidikan Tinggi.

\section{Jurnal}

Anshoruddin. Lembaga Wasiat Waiibah dalam Kompilasi Hukum Islam dalam Perspektif Sosiologi. Dalam Syahr, Z. H. A. (2016). Wasiat Wajibah sebagai Wujud Penyelesaian Perkara Waris Beda Agama dalam Perkembangan Sosial Masyarakat. Holistik, 1(2). 123-133. DOI: 10.24235/holistik.v1i2.905

Apriyudi, Eka. (2018). Pembagian Harta Warisan Anak Kandung Non Muslim Melalui Wasiat Wajibah. Jurnal Kertha Patrika, 40(1). 45-60. DOI: 10.24843/KP.2018.v40.i01.p05.

Arif, M. R. (2017). Pemberian Wasiat Wajibah terhadap Ahli Waris Beda Agama. DE LEGA LATA: Jurnal Ilmu Hukum, 2(2).

Bachtiar, M. (2012). Hukum Waris Islam Dipandang Dari Perspektif Hukum Berkeadilan Gender. Jurnal Ilmu Hukum, 1-43.DOI: http://dx.doi.org/10.30652/jih.v3i01.1026

Hidavati, S. (2012). Ketentuan wasiat wajibah di pelbagai negara Muslim kontemporer. AHKAM: Jurnal Ilmu Syariah, 12(1). 81-90.DOI: 10.15408/ajis.v12i1.982.

Mandasari, Zayanti. (2014).Politik Hukum Pengaturan Masyarakat Hukum Adat (Studi Putusan Mahkamah Konstitusi). Jurnal Hukum IUS QUIA IUSTUM. 2(1).227250. DOI: https://doi.org/10.20885/iustum.vol21.iss2.art4

Noviyanti, Liana. (2019). Penerapan Wasiat Wajiban Terhadap Non Muslim Ditinjau Dari Kompilasi Hukum Islam (KHI) Studi Kasus Putuan Mahkamah Agung No.331/K/AG/2018/MA. Jurnal Hukum Adigama, 2(2). 1-29. DOI: http://dx.doi.org/10.24912/adigama.v2i2.6533

Nugraheni, D. B., Ilhami, H., \& Harahab, Y. (2010). Pengaturan dan implementasi wasiat waiibah di Indonesia. Mimbar Hukum-Fakultas Hukum Universitas Gadjah Mada, 22(2). 311-329.DOI: https://doi.org/10.22146/jmh.16229

Raharjo, A. P., \& Putri, E. F. D. (2019). Analisis Pemberian Wasiat Wajibah terhadap Ahli Waris Beda Agama Pasca Putusan Mahkamah Agung Nomor 331 K/Ag/2018. Jurnal Suara Hukum, 1(2). 172-185. DOI: http://dx.doi.org/10.26740/jsh.v1n2.p172-185

Ramdhani, Ria. (2015). Pengaturan Wasiat Waiibah Terhadap Anak Angkat Menurut Hukum Islam. Lex et Societatis, 3(1). 55-63. DOI: http://10.31219/osf.io/9f5cj 
Rizkal, R. (2016). Pemberian Hak Waris Dalam Hukum Islam Kepada Non-Muslim Berdasarkan Wasiat Wajibah. Jurnal Yudisial, 9(2). 73-19.DOI: http://dx.doi.org/10.29123/jy.v9i2.23

Sonata, Depri Liber. (2017). Metode Penelitian Hukum Normatif dan Empiris: Karakteristik Khas Dari Metode Meneliti Hukum. Fiat Justitia: Jumal Ilmu Hukum. 8(1), 1-35. h.25. DOI: 10.25041/fiatjustisia.

\section{Peraturan Perundang-Undangan}

Undang-Undang Republik Indonesia Nomor 1 Tahun 1974 tentang Perkawinan, Lembaran Negara Republik Indonesia Tahun 1974 Nomor 1, Tambahan Lembaran Negara Republik Indonesia Nomor 3019.

Undang- Undang Nomor 48 Tahun 2009 Tentang Kekuasaaan Kehakiman, Lembaran Negara Republik Indonesia Tahun 2009 Nomor 157, Tambahan Lembaran Negara Republik Indonesia Nomor 5076

Instruksi Presiden Republik Indonesia Nomor 1 Tahun 1991 tentang Penyebarluasan Kompilasi Hukum Islam, Lembaran Lepas Sekretariat Negara Tahun 1991. 